\title{
EFFECT OF OPERATING PATTERNS ON THE EFFECTIVENESS OF LAW ENFORCEMENT IN THE SEA
}

\author{
Rully Tri Anggoro \\ Indonesian Naval Command and Staff School, \\ Seskoal-Cipulir, Jakarta 12230, Indonesia
}

\begin{abstract}
Indonesian Navy as a Security Task Force at Sea tasked with arranging marine security operations seeks to reduce the crime rate at sea. However, in carrying out marine operations there are still many illegal fishing, illegal logging, pollution, narcotics smuggling, piracy, people smuggling and sea accidents at various points in the sea. Koarmada II. Koarmada II in supporting the demand for operations that are under the command of its control, will be adjusted to the readiness of the existing elements, because not all elements below are in a condition ready for operation, there are several elements that must carry out maintenance and repair. Therefore we need the right operating pattern strategy in increasing the effectiveness of law enforcement at sea. The purpose of this research is to find out the right Indonesian Navy Operation Pattern in increasing the effectiveness of law enforcement at sea and the effect of the Operational Pattern on the effectiveness of sea law enforcement carried out by Indonesian Navy. Using the multiple regression analysis method, the results show that the Indonesian Navy Operational Pattern consisting of Patrol Operation Pattern (X1), Standby Operating Pattern (X2) and Air Maritime Patrol Operation Pattern (X3) has a real influence on the effectiveness of law enforcement at sea ( $Y$ ). The Air Maritime Patrol Operation Pattern (X3) has the greatest coefficient in influencing the Effectiveness Level of law enforcement at sea due to the use of the Air Maritime Patrol Operation Pattern so that it can explore the area very efficiently and effectively, thereby increasing opportunities to find violations of Law at sea.
\end{abstract}

Keywords: Operational Patterns, Effectiveness of Law Enforcement, Multiple Regression analysis.

\section{INTRODUCTION}

A geostrategic center that has the potential to unite and also has the potential to become a source of conflict between regions / countries. Indonesia has four of the world's nine sea lines of communication (SLOC) which has resulted in Indonesia having a very large obligation in ensuring the safety and security of international shipping. (UNCLOS, 1982)

Fleet Command II is the main operational and guidance command that is located directly under the TNI Commander in the field of operations and directly under Kasal. The duties and functions of Indonesian Navy are as operational implementers and have the main task of carrying out force projections to conduct daily sea operations in the form of marine security patrols, both aimed at law enforcement at national and international seas and creating favorable conditions for naval combat operations in the framework of enforcement of national sovereignty sovereignty.

\section{MATERIALS AND METHODS.}

2.1. Effectiveness of Law Enforcement. According to Soerjono Soekanto, law enforcement is an activity to harmonize the relations of values that are set out in the rules / views of values that are steady and manifest and act as a series of translation of the final stage of value to create, preserve and maintain peaceful social relations. Concrete law enforcement is positive law enforcement in practice as it should be obeyed. Therefore, giving justice in a case means deciding the law in concrete in maintaining and guaranteeing compliance with material law by using procedural methods determined by formal law. Effectiveness is basically the level of success in achieving goals that have been set or predetermined. the effectiveness of law is a process that aims to make the law effective. (Soerjono Soekanto)

\subsection{Definition of Multiple Regression analysis.}

Regression Analysis is used by researchers in order to find out how much influence the value of the dependent variable if the value of the independent variable is changed (Sugiyono, 2004: 206). Regression is useful for analyzing between one with another variable conceptually having a causal relationship.

$\mathrm{Y}=\mathrm{a}+\mathrm{bX}$

Values $a$ and $b$ can be obtained using the formula : (Y) $(\mathrm{X} 21)(\mathrm{X} 1)(\mathrm{X} 1 \mathrm{Y})$

$$
\begin{aligned}
& a=\frac{n X 21-(X 1) 2}{n(X 1 Y)-(X 1)(Y)} \\
& b=\frac{n 21-(X 1) 2}{n}
\end{aligned}
$$

Where : 
$\mathrm{Y}=$ Subject / Value in the predicted dependent variable

$\mathrm{a}=$ Price of $\mathrm{Y}$ if $\mathrm{X}=0$ (constant price)

$\mathrm{b}=$ Number of direction or coefficient of regression, which shows the number of increase or decrease in the dependent variable based on the independent variable. If $b(+)$ there will be an increase, and if (-) there will be a decrease.

$X=$ Subject to the independent variable that has a certain value.

Conditions:

If $b=0$, then the independent variable does not affect the dependent variable.

If $b>0$, then the independent variable does not affect the dependent variable.

If $b>0$, then the independent variable has $a$ negative effect on the dependent variable.

Furthermore, the results of calculating the correlation between variables from the Regression analysis can be guided by the table below:

Table 1. Guidelines for giving Interpretation of the Correlation Coefficient

\begin{tabular}{|c|c|}
\hline Internal & $\begin{array}{c}\text { Coefficient of } \\
\text { Relationship Level }\end{array}$ \\
\hline $0.00-0.1999$ & Very low \\
\hline $0.20-0.3999$ & Low \\
\hline $0.40-0.5999$ & Medium \\
\hline $0.60-0.7999$ & Strong \\
\hline $0.80-1.0000$ & Very Strong \\
\hline
\end{tabular}

Source: Sugiyono (2004: 183)

To find out if it is true that the independent variable has a relationship with the dependent variable, it can be done using a t test with a significant level of $5 \%$, then the results of the test are compared with the table. If $t$ arithmetic is smaller than or equal to the table then the variable $X$ does not have a relationship with the variable $Y$ while if $t$ arithmetic is greater than $t$ then the variable $X$ has a relationship with the variable $Y$. It explains with the Flowchart above this.

Fig 1. Flowchart of Regression Analysis

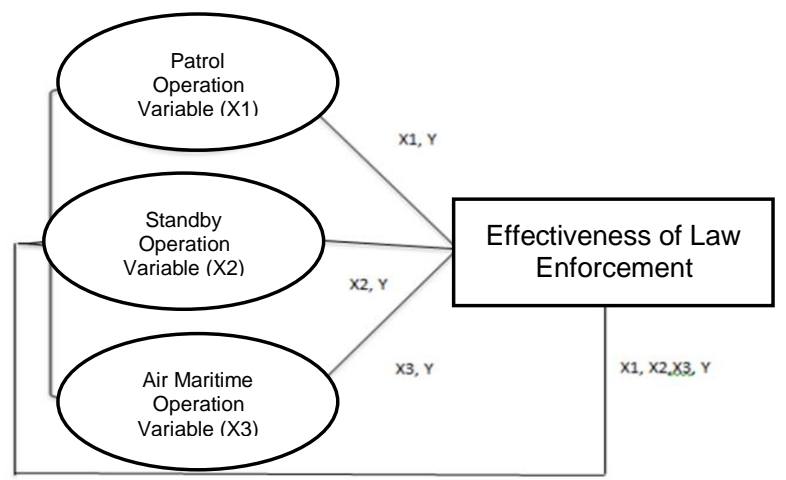

The research used in writing this thesis is a quantitative method. Quantitative Method is a research method based on the philosophy of positivism, used to examine a population or a specific sample, collecting data using research instruments, analyzing quantitative / statistical data, with the aim of testing a predetermined hypothesis. In this study the authors collected data with the following techniques:

a. Field work research. Namely direct data collection which is the object of research to look closely at the company, using the method: Observation (observation), Interview (interview), Questionnaire

b. Library research. It is the way to collect secondary data or data obtained through data that has been recorded, both in the form of reports and the results of previous research?

\section{RESULTS AND DISCUSSION.}

From the results of the answers disseminated in Indonesian Navy as an element of the implementation of Operation of Law Enforcement at Sea, questionnaires were filled in with 30 respondents, it can be seen in table 1 . below, where in the Patrol Operations, Wait and Maritime Patrol Operations variables are divided into 9 indicators then made into 9 item questions in order to obtain a picture expected by researchers of these variables while the results of the responses of the respondents can be seen through the answers in table 2 below

Table 2. Distribution of Answers for Variable Operational Patterns for Patrol, Standby and Air Maritime Patrol.

\begin{tabular}{|c|c|c|c|c|c|c|}
\hline \multirow{2}{*}{ Variable } & \multirow{2}{*}{ Indicator } & \multicolumn{5}{|c|}{ Score } \\
\hline & & SS & $S$ & KS & TS & STS \\
\hline \multirow{9}{*}{$\begin{array}{l}5 \\
\frac{5}{0} \\
\frac{ \pm}{\pi} \\
0 \\
\frac{c}{0} \\
0 \\
\frac{0}{\pi} \\
\frac{\pi}{0} \\
\frac{0}{0} \\
\frac{0}{0} \\
\frac{0}{0} \\
0\end{array}$} & 1 & 5 & 14 & 8 & 3 & 0 \\
\hline & 2 & 11 & 7 & 6 & 6 & 0 \\
\hline & 3 & 7 & 8 & 8 & 7 & 0 \\
\hline & 4 & 11 & 7 & 6 & 6 & 0 \\
\hline & 5 & 12 & 6 & 9 & 3 & 0 \\
\hline & 6 & 13 & 7 & 7 & 3 & 0 \\
\hline & 7 & 11 & 8 & 5 & 6 & 0 \\
\hline & 8 & 8 & 7 & 8 & 7 & 0 \\
\hline & 9 & 12 & 7 & 5 & 6 & 0 \\
\hline \multicolumn{2}{|c|}{ Total } & 90 & 71 & 62 & 47 & 0 \\
\hline \multirow{2}{*}{ Variable } & \multirow{2}{*}{ Indicator } & \multicolumn{5}{|c|}{ Score } \\
\hline & & SS & $S$ & $\mathrm{KS}$ & TS & STS \\
\hline \multirow{9}{*}{ 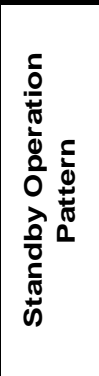 } & 1 & 8 & 9 & 8 & 5 & 0 \\
\hline & 2 & 11 & 8 & 4 & 7 & 0 \\
\hline & 3 & 8 & 9 & 8 & 5 & 0 \\
\hline & 4 & 13 & 8 & 3 & 6 & 0 \\
\hline & 5 & 6 & 13 & 8 & 3 & 0 \\
\hline & 6 & 11 & 8 & 5 & 6 & 0 \\
\hline & 7 & 7 & 9 & 8 & 6 & 0 \\
\hline & 8 & 11 & 9 & 5 & 5 & 0 \\
\hline & 9 & 7 & 7 & 8 & 8 & 0 \\
\hline \multicolumn{2}{|c|}{ Total } & 82 & 80 & 57 & 51 & 0 \\
\hline
\end{tabular}




\begin{tabular}{|c|c|c|c|c|c|c|}
\hline \multirow{2}{*}{ Variable } & \multirow{2}{*}{ Indicator } & \multicolumn{5}{|c|}{ Score } \\
\hline & & SS & $\mathrm{S}$ & $\mathrm{KS}$ & TS & STS \\
\hline \multirow{9}{*}{ 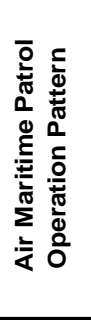 } & 1 & 10 & 11 & 6 & 3 & 0 \\
\hline & 2 & 8 & 14 & 7 & 1 & 0 \\
\hline & 3 & 10 & 12 & 6 & 2 & 0 \\
\hline & 4 & 11 & 11 & 6 & 2 & 0 \\
\hline & 5 & 12 & 10 & 6 & 2 & 0 \\
\hline & 6 & 10 & 11 & 7 & 2 & 0 \\
\hline & 7 & 10 & 10 & 7 & 3 & 0 \\
\hline & 8 & 11 & 9 & 9 & 1 & 0 \\
\hline & 9 & 10 & 11 & 6 & 3 & 0 \\
\hline \multicolumn{2}{|c|}{ Total } & 92 & 99 & 60 & 19 & 0 \\
\hline
\end{tabular}

In order to obtain a percentage of each answer to the operating pattern variable presented in table 3.

Table 3. Evaluation of Respondents on the Variable Patterns of Patrol, Standby and Air Maritime Patrol Operations.

\begin{tabular}{|c|c|c|c|}
\hline \multicolumn{4}{|c|}{ Patrol Operation Pattern } \\
\hline Score & Total & $\begin{array}{c}\text { Score } \mathrm{x} \\
\text { Total }\end{array}$ & Percentage \\
\hline 5 & 90 & 450 & $44 \%$ \\
\hline 4 & 71 & 284 & $28 \%$ \\
\hline 3 & 62 & 186 & $18 \%$ \\
\hline 2 & 47 & 94 & $9 \%$ \\
\hline 1 & 0 & 0 & $0 \%$ \\
\hline Total & & 1014 & $100 \%$ \\
\hline \multicolumn{4}{|c|}{ Standby Operation Pattern } \\
\hline Score & Total & $\begin{array}{c}\text { Score } \mathbf{x} \\
\text { Total }\end{array}$ & Percentage \\
\hline 5 & 82 & 410 & $41 \%$ \\
\hline 4 & 80 & 320 & $32 \%$ \\
\hline 3 & 57 & 171 & $17 \%$ \\
\hline 2 & 51 & 102 & $10 \%$ \\
\hline 1 & 0 & 0 & $0 \%$ \\
\hline Total & & 1003 & $100 \%$ \\
\hline \multicolumn{4}{|c|}{ Air Maritime Patrol Operation Pattern } \\
\hline Score & Total & $\begin{array}{c}\text { Score } x \\
\text { Total }\end{array}$ & Percentage \\
\hline 5 & 92 & 460 & $43 \%$ \\
\hline 4 & 99 & 396 & $37 \%$ \\
\hline 3 & 60 & 180 & $17 \%$ \\
\hline 2 & 19 & 38 & $4 \%$ \\
\hline 1 & 0 & 0 & $0 \%$ \\
\hline Total & & 1074 & $100 \%$ \\
\hline
\end{tabular}

From the results of the above table it can be explained that there are variations in each respondent's answer. The score with the largest percentage is at a score of 5 , with a percentage of $44 \%$. Ideally, the highest expected score of respondents' answers to questions about this Patrol Operation Pattern variable is 5 (highest score) $\times 9$ (number of question items) $\times 30$ (number of respondents) $=1350$, Thus the recapitulation of the respondent's answer distribution shows that the score obtained is 1014 or $75 \%$. As for the Operating
Pattern Wait, the largest percentage is at a score of 5 , with a percentage of $41 \%$. Ideally, the highest expected score of respondents' answers to questions about the determinant dimensions of these behavioral boundaries is 5 (highest score) $\times 9$ (number of question items) $\times 30$ (number of respondents) $=1350$. Thus the recapitulation of the respondent's answer distribution indicates that the score obtained is 1003 or $74.3 \%$. Then for the Air Maritime Patrol Variable the largest percentage is at a score of 5 , with a percentage of $43 \%$. Ideally, the highest expected score of respondents' answers to questions about the Air Maritime Patrol Operational Pattern as part of this organization is 5 (highest score) $\times 9$ (number of question items) $\times 30$ (number of respondents) $=1350$. Thus the recapitulation of the responses of respondents shows that the score obtained is 1074 or $79.5 \%$. Of the criteria set, if interpreted the value of $79.5 \%$. This means that most respondents gave an assessment that the Pattern of Patrol, Standby and Air Maritime Patrol Operations in Indonesian Navy Work Unit was in a good position.

For Dependent Variables the questionnaire distribution obtained is shown in table 4 .

Table 4. Distribution of Answers for Variables Effectiveness of Law Enforcement at Sea.

\begin{tabular}{|c|c|c|c|c|c|c|}
\hline \multirow{2}{*}{ Variable } & \multirow{2}{*}{ Indicator } & \multicolumn{5}{|c|}{ Score } \\
\hline & & SS & $S$ & $\mathrm{KS}$ & TS & STS \\
\hline \multirow{11}{*}{ 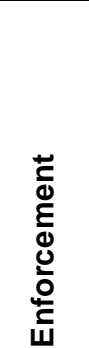 } & 1 & 12 & 7 & 7 & 4 & 0 \\
\hline & 2 & 14 & 6 & 7 & 3 & 0 \\
\hline & 3 & 13 & 6 & 8 & 3 & 0 \\
\hline & 4 & 14 & 6 & 7 & 3 & 0 \\
\hline & 5 & 12 & 6 & 8 & 4 & 0 \\
\hline & 6 & 12 & 6 & 8 & 4 & 0 \\
\hline & 7 & 12 & 7 & 7 & 4 & 0 \\
\hline & 8 & 12 & 6 & 8 & 4 & 0 \\
\hline & 9 & 12 & 7 & 7 & 4 & 0 \\
\hline & 10 & 11 & 7 & 5 & 7 & 0 \\
\hline & 11 & 7 & 7 & 8 & 8 & 0 \\
\hline \multirow{14}{*}{ 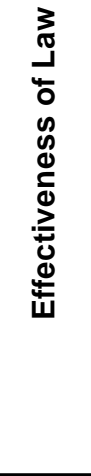 } & 12 & 11 & 7 & 5 & 7 & 0 \\
\hline & 13 & 7 & 7 & 8 & 8 & 0 \\
\hline & 14 & 11 & 7 & 5 & 7 & 0 \\
\hline & 15 & 7 & 7 & 8 & 8 & 0 \\
\hline & 16 & 13 & 7 & 3 & 7 & 0 \\
\hline & 17 & 5 & 13 & 8 & 4 & 0 \\
\hline & 18 & 11 & 7 & 5 & 7 & 0 \\
\hline & 19 & 7 & 7 & 8 & 8 & 0 \\
\hline & 20 & 11 & 7 & 5 & 7 & 0 \\
\hline & 21 & 7 & 7 & 8 & 8 & 0 \\
\hline & 22 & 13 & 7 & 3 & 7 & 0 \\
\hline & 23 & 11 & 7 & 5 & 7 & 0 \\
\hline & 24 & 7 & 7 & 8 & 8 & 0 \\
\hline & 25 & 13 & 7 & 3 & 7 & 0 \\
\hline \multicolumn{2}{|c|}{ Total } & 265 & 175 & 162 & 148 & 0 \\
\hline \multicolumn{7}{|c|}{ Effectiveness of Law Enforcement } \\
\hline \multicolumn{2}{|c|}{ Score } & Total & \multicolumn{2}{|c|}{$\begin{array}{c}\text { Score } x \\
\text { Total }\end{array}$} & \multicolumn{2}{|c|}{ Percentage } \\
\hline \multicolumn{2}{|c|}{5} & 265 & \multicolumn{2}{|c|}{1325} & \multicolumn{2}{|c|}{$47 \%$} \\
\hline \multicolumn{2}{|c|}{4} & 175 & \multicolumn{2}{|c|}{700} & \multicolumn{2}{|c|}{$25 \%$} \\
\hline \multicolumn{2}{|c|}{3} & 162 & \multicolumn{2}{|c|}{486} & \multicolumn{2}{|c|}{$17 \%$} \\
\hline \multicolumn{2}{|c|}{2} & 148 & \multicolumn{2}{|c|}{296} & \multicolumn{2}{|c|}{$11 \%$} \\
\hline \multicolumn{2}{|c|}{1} & $\mathrm{O}$ & \multicolumn{2}{|c|}{$\mathrm{O}$} & \multicolumn{2}{|c|}{$0 \%$} \\
\hline \multicolumn{2}{|c|}{ Total } & & \multicolumn{2}{|c|}{2807} & \multicolumn{2}{|c|}{$100 \%$} \\
\hline
\end{tabular}


Table 4 shows the variation in each respondent's answer. Where the Score with the largest percentage is at a score of 5 , with a percentage of $47 \%$. Ideally, the highest expected score of respondents' answers to questions about the effectiveness of the Law enforcement variable at Sea is 5 (highest score) $\times 25$ (number of question items) $\times 30$ (number of respondents) $=3750$. Thus the recapitulation of the respondent's answer distribution indicates that the score obtained is 2807 or $74.9 \%$. From the determined criteria, if interpreted the value of $74.9 \%$ lies in the score of good value. This means that most respondents gave an assessment that the effectiveness of law enforcement at sea through the Pattern of Operations in Indonesian Navy was in a good position.

Based on the validity test, the results of testing the validity of the answer score for each question from the Patrol Operation Variable, Wait Operation Variable, Air Maritime Patrol and Law Enforcement Effectiveness Variables conducted by respondents were 30 officers serving in the Indonesian Navy Unit, through the calculation of the $R$ value can be seen in the following table:

Table 5.a. Test Results of Variable Validity in Patrol Operation Pattern (X1)

\begin{tabular}{|c|c|c|l|}
\hline Item & \multicolumn{2}{|c|}{$\mathrm{X} 1$} & \multirow{2}{*}{ Validation } \\
\cline { 1 - 3 } Question & r Result & r Table & \\
\hline 1 & 0.56819 & 0.361 & Valid \\
\hline 2 & 0.79127 & 0.361 & Valid \\
\hline 3 & 0.54215 & 0.361 & Valid \\
\hline 4 & 0.79127 & 0.361 & Valid \\
\hline 5 & 0.51603 & 0.361 & Valid \\
\hline 6 & 0.49386 & 0.361 & Valid \\
\hline 7 & 0.78395 & 0.361 & Valid \\
\hline 8 & 0.50491 & 0.361 & Valid \\
\hline 9 & 0.75764 & 0.361 & Valid \\
\hline
\end{tabular}

Table 5.b.Test Results of Variable Validity in Standby Operation Pattern (X2).

\begin{tabular}{|c|c|c|l|}
\hline Item & \multicolumn{2}{|c|}{ X2 } & \multirow{2}{*}{ Validation } \\
\cline { 1 - 2 } Question & r Result & r Table & \\
\hline 1 & 0.63515 & 0.361 & Valid \\
\hline 2 & 0.57274 & 0.361 & Valid \\
\hline 3 & 0.64066 & 0.361 & Valid \\
\hline 4 & 0.41808 & 0.361 & Valid \\
\hline 5 & 0.51199 & 0.361 & Valid \\
\hline 6 & 0.58919 & 0.361 & Valid \\
\hline 7 & 0.70093 & 0.361 & Valid \\
\hline 8 & 0.53769 & 0.361 & Valid \\
\hline 9 & 0.77426 & 0.361 & Valid \\
\hline
\end{tabular}

Table 5.c. Test Results of Variable Validity in Air Maritime Patrol Operation Pattern (X3).

\begin{tabular}{|c|c|c|l|}
\hline Item & \multicolumn{2}{|c|}{ X3 } & \multirow{2}{*}{ Validation } \\
\cline { 1 - 3 } Question & r Result & r Table & \\
\hline 1 & 0.90343 & 0.361 & Valid \\
\hline 2 & 0.75101 & 0.361 & Valid \\
\hline 3 & 0.82220 & 0.361 & Valid \\
\hline 4 & 0.72659 & 0.361 & Valid \\
\hline 5 & 0.81521 & 0.361 & Valid \\
\hline 6 & 0.84267 & 0.361 & Valid \\
\hline 7 & 0.89924 & 0.361 & Valid \\
\hline 8 & 0.69065 & 0.361 & Valid \\
\hline 9 & 0.94412 & 0.361 & Valid \\
\hline
\end{tabular}

From the results contained in the above table, the questionnaire / questionnaire instrument against the respondent is declared valid if the calculated $R$ value is greater than the table value, so based on these requirements, the items in the questionnaire / adoption related to Independent and Dependent Variables are declared fully valid.

Table 5.d. Test Results of Variable Validity Effectiveness Law Enforcement $(\mathrm{Y})$

\begin{tabular}{|c|c|c|l|}
\hline Item & \multicolumn{2}{|c|}{$Y$} & \multirow{2}{*}{ Validation } \\
\cline { 1 - 3 } Question & r Result & r Table & \\
\hline 1 & 0.77995 & 0.361 & Valid \\
\hline 2 & 0.75715 & 0.361 & Valid \\
\hline 3 & 0.73864 & 0.361 & Valid \\
\hline 4 & 0.75715 & 0.361 & Valid \\
\hline 5 & 0.75927 & 0.361 & Valid \\
\hline 6 & 0.75927 & 0.361 & Valid \\
\hline 7 & 0.77995 & 0.361 & Valid \\
\hline 8 & 0.75927 & 0.361 & Valid \\
\hline 9 & 0.77995 & 0.361 & Valid \\
\hline 10 & 0.52992 & 0.361 & Valid \\
\hline 11 & 0.77711 & 0.361 & Valid \\
\hline 12 & 0.52992 & 0.361 & Valid \\
\hline 13 & 0.77711 & 0.361 & Valid \\
\hline 14 & 0.52992 & 0.361 & Valid \\
\hline 15 & 0.77711 & 0.361 & Valid \\
\hline 16 & 0.52561 & 0.361 & Valid \\
\hline 17 & 0.49574 & 0.361 & Valid \\
\hline 18 & 0.52992 & 0.361 & Valid \\
\hline 19 & 0.77711 & 0.361 & Valid \\
\hline 20 & 0.52992 & 0.361 & Valid \\
\hline 21 & 0.77711 & 0.361 & Valid \\
\hline 22 & 0.52561 & 0.361 & Valid \\
\hline 23 & 0.52992 & 0.361 & Valid \\
\hline 24 & 0.77711 & 0.361 & Valid \\
\hline 25 & 0.52561 & 0.361 & Valid \\
\hline & & & \\
\hline
\end{tabular}


Furthermore, reliability testing Reliability is the level of confidence in the results of a measurement. Measurements that have high reliability, namely measurements that are able to provide reliable measurement results (reliable). Although theoretically the magnitude of the reliability coefficient is around 0.00 to 1.00 but in reality a coefficient of 1.00 has never been reached in measurement, because humans as research subjects are potential sources of error. So that the results obtained as the following table:

Table 6a. Statistical reliability results for the Patrol Operation Pattern variable (X1)

\section{Reliability Statistics}

\begin{tabular}{|c|c|}
\hline $\begin{array}{c}\text { Cronbach' } \\
\text { s Alpha }\end{array}$ & N of Items \\
\hline 0.82 & 9 \\
\hline
\end{tabular}

Table 6.b.Statistical results for reliability for the variable Standby Operation Pattern (X2)

\section{Reliability Statistics}

\begin{tabular}{|c|c|}
\hline $\begin{array}{c}\text { Cronbach' } \\
\text { s Alpha }\end{array}$ & N of Items \\
\hline 0.77 & 9 \\
\hline
\end{tabular}

Table 6.c. Statistical results for reliability for Variable Air Maritime Patrol Operating Pattern (X3)

\section{Reliability Statistics}

\begin{tabular}{|c|c|}
\hline $\begin{array}{c}\text { Cronbach' } \\
\text { s Alpha }\end{array}$ & N of Items \\
\hline 0.94 & 9 \\
\hline
\end{tabular}

Table 6.d. Statistical reliability results for variables Effectiveness of Law Enforcement at sea ( $\mathrm{Y}$ )

\section{Reliability Statistics}

\begin{tabular}{|c|c|}
\hline $\begin{array}{c}\text { Cronbach' } \\
\text { s Alpha }\end{array}$ & N of Items \\
\hline 0.94 & 9 \\
\hline
\end{tabular}

The reliability value of each variable gives an indication that the reliability of the questionnaire / questionnaire used as a measure is included in the category of strong correlations for each variable. This Reliability Test gives an indication that the reliability of the questionnaire / questionnaire used as a gauge for the variable Operational Patterns and Effectiveness of Law Enforcement at sea by Indonesian Navy is included in the high category and is accepted. This is because each alpha value exceeds the cut-off value of 0.6 , and then all items are reliable.

The results of data processing with multiple regression analysis obtained the following results: a. $\quad$ Partial Test ( $t$ test)

The results of the $t$ test in this study can be seen in the following table:

Table 7. T test

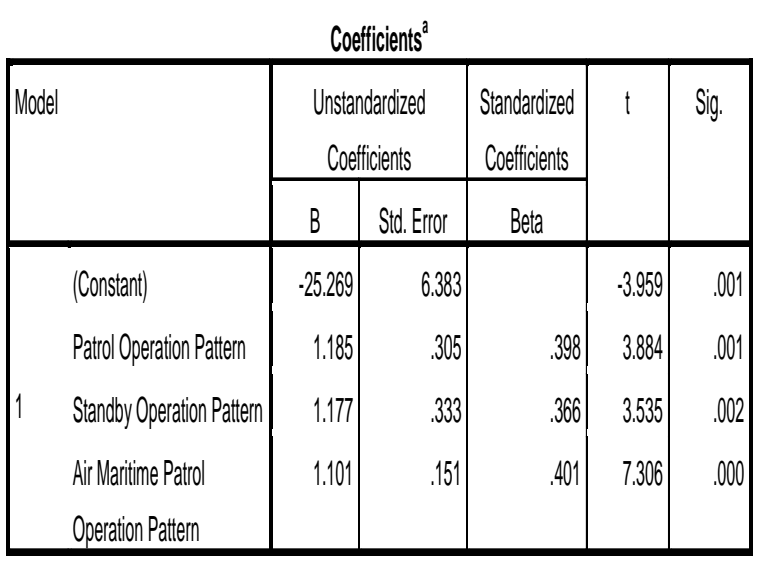

Based on the table above, the results of the $t$ test in this study can be explained as follows:

1) Variable (X1)

$T$ test results for the Patrol Operation Pattern variable (X1) showed a calculated $t$ value of 3.88 . This means that the calculated $t$ value is greater than t table 2.05553 for alpha 0.05 with a sample size of 30 so that the obtained degree of free value is 26 , in addition to looking at the significance value it can be seen that the significance value of variable $\mathrm{X} 1$ has a value smaller than alpha value 0,05 . On the basis of these two comparisons, it can be concluded that there is an influence of the Patrol Operations Pattern (X1) on the Effectiveness of Law Enforcement in The Sea by Indonesian Navy.

2) Variables (X2)

$T$ test results for the Wait Operation Pattern (X2) variable showed the calculated t value of 3.53. This means that the calculated $t$ value is greater than $t$ table 2.05553 for alpha 0.05 with a sample size of 30 to obtain a free degree of value 26 , besides that by looking at the significance value it appears that the significance value of the variable $\mathrm{X} 2$ has a value smaller than the alpha value of 0 , 05. On the basis of these two comparisons, it can be concluded that there is an effect of the Standby Operation Pattern (X2) on the Effectiveness of Law Enforcement in The Sea by Indonesian Navy.

3) Variables (X3)

$T$ test results for the Air Maritime Patrol Operational Pattern (X3) variable showed a calculated $t$ value of 7.03 . This means that the calculated $t$ value is greater than t table 2.05553 for alpha 0.05 with a sample size of 30 to obtain a free degree of value 27 , besides that by looking at the significance value it appears that the significance value of the variable $X 3$ has a value smaller than the alpha value of 0,05 . On the basis of these two comparisons, it can be concluded that there is an influence of the Air Maritime Patrol (X3) Operation Pattern on the Effectiveness of Law Enforcement in The Sea by Indonesian Navy. 
b. Simultaneous Test (F Test)

Table 8. F test

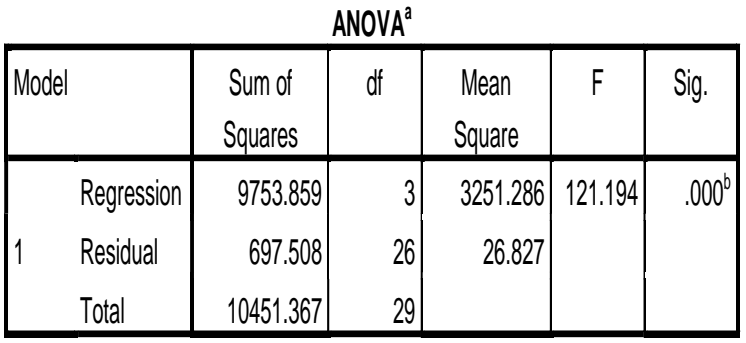

$\mathrm{F}$ Test results show the calculated $\mathrm{F}$ value of 121,194 . This means that the $F$ count is greater than the $\mathrm{F}$ table 2.98. with the degree of free 1 that is used by looking at the number of independent variables used is 3 and the degree of free 2 is obtained from the number of samples 30 minus the number of independent variables and minus 1 so that obtained $30-3-1$ is 26 , and by looking at the significance value obtained is smaller of the alpha value of 0.05 . So on the basis of these two comparisons, the model used is appropriate.

\section{c. Determination Test}

Meanwhile, how much influence the Patrol Operation Pattern (X1), Standby Operational Pattern (X2) and Air Maritime Patrol Operational Pattern (X3) in explaining the variable effectiveness of Law Enforcement by the Sea by Indonesian Navy, can be seen in the table below

Table 8. Calculation Results for the Determination Coefficient of Variable $X$ with $Y$

\begin{tabular}{|l|l|r|r|r|}
\hline Model & \multicolumn{1}{|c|}{ Model Summary } & R Square & $\begin{array}{c}\text { Adjusted R } \\
\text { Square }\end{array}$ & $\begin{array}{c}\text { Std. Error of the } \\
\text { Estimate }\end{array}$ \\
\hline 1 & $.966^{\mathrm{a}}$ & .933 & .926 & 5.17950 \\
\hline
\end{tabular}

The value of $R$ in the table above states that the relationship between the independent variables in influencing the dependent variable $(\mathrm{Y})$ is quite strong, which is equal to 0.966. While the Determination Coefficient shown in the R-Square value or equal to 0.933 shows that the variable capability of Patrol Operation Pattern (X1), Standby Operating Pattern (X2) and Air Maritime Patrol Operational Pattern (X3) in explaining the Effectiveness of Law Enforcement by Sea Indonesian Navy is equal to $93.3 \%$, while the remaining $6.3 \%$ is influenced by other variables not included in the model.

\section{Hypothesis Testing}

1) Partial Indonesian Navy operating patterns on the effectiveness of law enforcement at sea

On the basis of the following hypothesis:

HO: Partial Indonesian Navy operating patterns do not affect the effectiveness of law enforcement at sea.
H1: Indonesian Navy's operational pattern partially influences the effectiveness of law enforcement at sea.

So from the results of data processing by looking at the $t$ test which is a partial test of influence between the three independent variables on the dependent variable, the significance value obtained is smaller than the alpha value of 0.05 then $\mathrm{Ho}$ is rejected and $\mathrm{H}_{\mathrm{I}}$ is accepted so it can be concluded that partially the Patrol Operation Pattern variable (X1), Standby Operation Pattern (X2) and Air Maritime Patrol Operational Pattern (X3) have an influence in explaining the variables of Law Enforcement Effectiveness at Sea by Indonesian Navy.

2) Simultaneous operational pattern of Indonesian Navy on the effectiveness of law enforcement at sea.

On the basis of the following hypothesis:

HO: Simultaneous operational pattern of Indonesian Navy does not affect the effectiveness of law enforcement at sea.

H1: Simultaneous operational pattern of Indonesian Navy has no effect on the effectiveness of law enforcement at sea.

Then from the results of data processing by looking at the F Test which is a test of simultaneous influence between the three independent variables on the dependent variable, the significance value obtained is smaller than the alpha value of 0.05 then $\mathrm{Ho}$ is rejected and $\mathrm{H}_{\mathrm{I}}$ is accepted so it can be concluded that simultaneously the Patrol Operation Pattern variable (X1), Standby Operation Pattern (X2) and Air Maritime Patrol Operational Pattern (X3) have an influence in explaining the variables of Law Enforcement Effectiveness at Sea by Indonesian Navy.

\section{CONCLUSION}

By looking at each of the variables partially the research seems clear for the Air Maritime Patrol operating pattern variable to have a greater influence value than the other variables in influencing the effectiveness of law enforcement in the Sea by Indonesian Navy. This is because the use of patrols using or through aircraft will be very effective because the time required is very little but still cannot stand alone because in the model of the three variables have an influence on the effectiveness of law enforcement at sea by Indonesian Navy.

Whereas related to the first variable, the Patrol operation pattern variable has a better influence only from the Wait Operation Variable variable. This clearly proves that the presence of the strength of the KRI dialaut will be more effective than the Wait Operation pattern method.

So based on the results obtained in answering the problem formulation, it can be seen that the three variables used are Patrol Operation Pattern (X1), Standby Operating Pattern (X2) and 
Air Maritime Patrol Operation Pattern (X3) have a real influence on the effectiveness of law enforcement in the sea by Indonesian Navy, and has been very effective in seeing the magnitude of the relationship between the independent variable and the dependent variable based on the value of $r$ squared. So it is clear that the current pattern of operations needs to be carried out continuously so that the effectiveness of law enforcement in the Sea of the Fleet II region can be maintained properly.

\section{REFERENCES}

Sugiyono (2004), Business Research Methods, CV. Alfabeta, Bandung

AT. Mahan ,. 1960-1783, The Influence of Sea Power Upon History, Twelfth Edition, Boston, Little Brown and Company, p. 82

RI Law Number 37 of 1999 dated September 14, 1999 concerning Foreign Relations.

J.G. Starke, (1989), Introduction to International Law (An Introduction on International Law), Translation of Sumitro Danuredja and Lukas Ginting, (Jakarta: Aksara Persada Indonesia, p. 143
Moenir (1998). General Service Management. Jakarta: Bumi Aksara, p. 116.18

Mochtar Kusumaatmadja, 1990, "Introduction to International Law", Bandung: Binacipta, p. 11.

https://www.researchgate.net/publication/24997417 2_The_Security_of_Sea_Lanes_in_Southeas t_Asia

https://scholarship.rice.edu/bitstream/handle/1911/7 1096/RegressionGuidebook.pdf?sequence $=3$ \&isAllowed=y

https://www.academia.edu/36968614/Prototype_Of Knowledge Management System Kms EProcurement_Web-Based_Case_Study_At _Pt.Sigma_Pro_77

http://www.iosrjournals.org/iosr-jef/papers/Vol9Issue5/Version-3/A0905030108.pdf 